\title{
Introduction and Expression of CAT Gene in Rainbow Trout
}

\author{
Goro Yoshizaki, ${ }^{* 1}$ Shuichi Kobayashi, ${ }^{* 1}$ Takashi Oshiro, ${ }^{* 1}$ \\ and Fumio Takashima*1,2 \\ (Received March 11, 1992)
}

\begin{abstract}
RSV-CAT (Chloramphenicol acetyltransferase gene linked to the long terminal repeat of Rous sarcoma virus) was microinjected into the cytoplasm of 1-cell stage rainbow trout eggs. Eggs were pretreated with reduced-glutathione to facilitate microinjection. The survival rates of microinjected eggs were $77 \%$ at the eyed stage, $74 \%$ at hatching, and $70 \%$ at swimming-up; this did not differ from these of the control group. Seventy-day-old fish were cut along the symmetry axis. Right and left side tissues were utilized for DNA analysis and CAT assay respectively. In 6 individuals out of 10, RSV-CAT was integrated into the host genome and formed head-totail and tail-to-tail concatemers. Furthermore, acetylated chloramphenicol was detected in 9 individuals (including the above mentioned 6) out of 10 . Therefore, these results suggest that in 6 out of 10 individuals RSV-CAT was expressed after integration into the host genome.
\end{abstract}

The study of foreign gene expression in host animals should be indispensable for the introduction of desirable genetic characters into individuals and their progeny by transgenic techniques. ${ }^{1-3)}$

Although several transgenic fish have been developed in recent years, ${ }^{4-8)}$ reports on the expression of introduced genes are very few. RNAtranscript of introduced gene was detected in goldfish, ${ }^{g)}$ and translation into protein was detected in medaka, ${ }^{10-19)}$ zebrafish, ${ }^{14,15)}$ carp, ${ }^{16)}$ Atlantic salmon, ${ }^{17,18)}$ and rainbow trout. ${ }^{18,19)}$ Thus, medaka and zebrafish have often been utilized as experimental animals for studies of foreign gene expression. However, very few studies on foreign gene expression have been performed in economically important species for aquaculture, such as salmonids and cyprinids. A major problem in the past has been the lack of suitable regulatory elements for transgene expression.

The objective of this study is the development of a suitable expression system for transgenic rainbow trout. For this purpose, we microinjected the RSV-CAT, chloramphenicol acetyltransferase (CAT) gene linked to the long terminal repeat (LTR) of Rous sarcoma virus (RSV), into fertilized eggs of rainbow trout (Oncorhynchus mykiss) and analyzed the fate and the expression of the injected gene.

RSV-LTR has strong promoter activity in various types of cells, derived from avian, mam- malian, ${ }^{20)}$ Xiphophorus, carp, ${ }^{, 11}$ and rainbow trout $^{22)}$ Furthermore, it is also active in transgenic individuals of mice, ${ }^{23)}$ medaka, ${ }^{13)}$ zebrafish, ${ }^{14)}$ carp, ${ }^{16)}$ and goldfish. ${ }^{97}$

The bacterial CAT enzyme has been utilized by Gorman et al. ${ }^{24)}$ as a useful indicator of chimeric gene activity in mammalian cells. This CAT assay is simple and sensitive as well as convenient. In addition, the CAT enzyme activity is completely absent in eukaryotic cells, so that background noise is not of concern.

In this study, we report the results of introduction and expression of CAT gene in rainbow trout.

\section{Materials and Methods}

\section{Construction of Plasmid}

Figure 1 is a scheme of the construction of the plasmid used in this study. The recombinant plasmid pRSVCAT contains a Nru I-Bst NI fragment of RSV-LTR (about 400b.p), ${ }^{25)}$ bacterial CAT gene, simian virus 40 (SV40) splicing signal, and SV40 poly adenylation signal ${ }^{24}$ (Fig. 1). This plasmid was digested with $\mathrm{Nru}$ I (Takara Shuzo Co. Ltd.) and Bam HI (Takara Shuzo Co. Ltd.), and the pUC 19 vector was eliminated by electrophoresis, using low melting point agarose. The purified $2.05 \mathrm{~kb}$ fragment (RSV-CAT) (Fig. 2) was dissolved in $10 \mathrm{~mm}$

*1 Laboratory of Fish-Culture, Tokyo University of Fisheries, Konan, Minato, Tokyo 108, Japan (吉崎悟

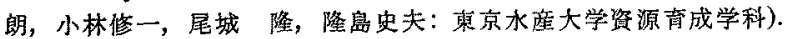

*2. To whom reprint requests should be addressed. 


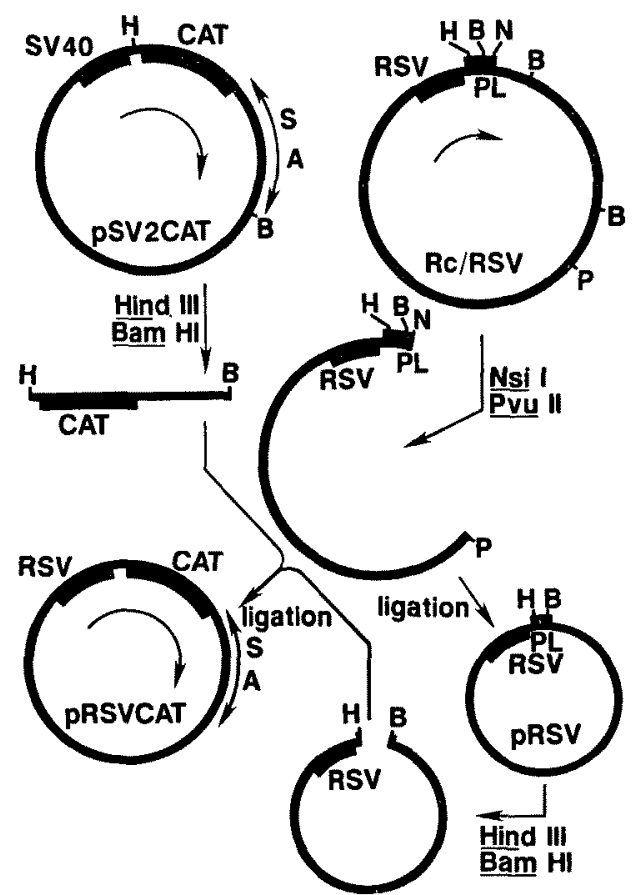

Fig. 1. Scheme for construction of the plasmid pRSVCAT. RC/RSV was purchased from Invitrogen Co. Ltd, and the Bam HI site was eliminated, except for the polylinker with $N s i$ I and $P v u$ II-digestion. pSV2CAT was digested with Bam HI and Hind III. This Bam HI-Hind III fragment containing CAT gene, polyadenylation signal, and splicing signal was ligated to the Bam $\mathrm{HI}$ and Hind III site of pRSV. B, Bam HI; H, Hind III; N, Nsi I; P, Pvu II; A, polyadenylation signal; S, splicing signal; PL, poly linker.

Tris- $\mathrm{HCl}(\mathrm{pH} 8.0)-0.1 \mathrm{~mm}$ EDTA at a concentration of $11.2 \mathrm{ng} / \mu \mathrm{l}$.

\section{Microinjection and Sampling}

In November 1990, microinjection was carried out between 2 and $5 \mathrm{~h}$ after fertilization. Two $\mathrm{n} l$ of DNA solution containing $10^{7}$ copies of RSVCAT was injected into the blastodisc of glutathione treated eggs $^{26)}$ of rainbow trout using techniques previously described. ${ }^{27)}$ The eggs were incubated at $10^{\circ} \mathrm{C}$. Seventy days after fertilization, individual fish were cut along the symmetry axis. Right and left side tissues were utilized for DNA and protein analyses respectively.

\section{Southern Blot Analysis}

DNA was extracted from the right side of 70 day-old fish as described previously. ${ }^{27)}$ Ten
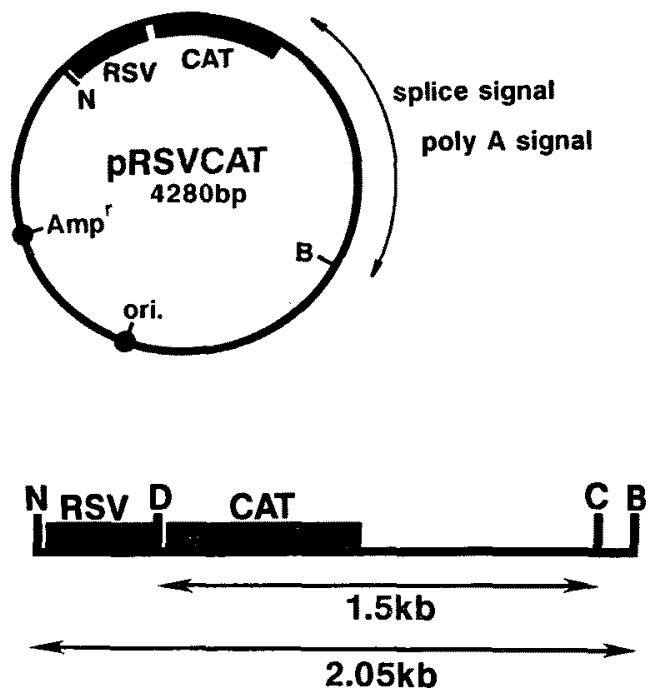

Fig. 2. Restriction maps of pRSVCAT (4280 bp) (top) and RSV-CAT (2.05 kb) (bottom). RSV; RSV-LTR; B, Bam HI; N, Nru I; C, Hinc III; D, Hind III.

$\mu \mathrm{g}$ of genomic DNA was digested with Hind III and Hinc II (Takara Shuzo Co. Ltd.), electrophoresed on a $1.0 \%$ agarose gel, and transferred to a nylon membrane. ${ }^{28)}$ Pre-hybridization was carried out in $5 \times$ SSPE $(0.75 \mathrm{M} \mathrm{NaCl}, 0.05 \mathrm{M}$ $\mathrm{NaH}_{2} \mathrm{PO}_{4} .2 \mathrm{H}_{8} \mathrm{O}, 0.005 \mathrm{M}$ EDTA, adjusted to pH 7.4), $5 \times$ Denhardt's solution $(0.1 \%$ Ficoll, $0.1 \%$ polyvinylpyrolidone, $0.1 \%$ bovine serum albumin), $50 \%$ formamide, $10 \%$ dextran sulfate, and $100 \mu \mathrm{g} / \mathrm{m} l$ of denatured calf thymus DNA at $42^{\circ} \mathrm{C}$ for $3 \mathrm{~h}$. Hybridization was carried out in the same buffer containing denatured probe RSV-CAT labelled with $\alpha^{-32} \mathrm{P}$ dCTP by random priming. The membrane was washed in $2 \times$ SSPE for $15 \mathrm{~min}$ at $65^{\circ} \mathrm{C}$, then in $1 \times$ SSPE and $0.5 \%$ SDS for $15 \mathrm{~min}$ at $65^{\circ} \mathrm{C}$, and finally in $0.2 \times$ SSPE and $0.5 \%$ SDS for $20 \mathrm{~min}$ at $65^{\circ} \mathrm{C}$, before autoradiography. In the case of positive samples, further Southern blot analyses were carried out, using Hind III-digested, Pst I (Takara Shuzo Co. Ltd.)-digested, and undigested DNA.

\section{CAT Assay}

CAT assay was performed according to the method of Gorman et al. ${ }^{24)}$ with slight modifications. For this purpose, the left side of 70-dayold fish was homogenized in $150 \mu \mathrm{l}$ of $0.25 \mathrm{M}$ Tris- $\mathrm{HCl}(\mathrm{pH} \mathrm{7.5)}$ and freeze-thawed three times. 
Table 1. Fertilization and early survival rates $(\%)$ of microinjected rainbow trout eggs of the following items

\begin{tabular}{lccccc}
\hline \multicolumn{1}{c}{ Group } & $\begin{array}{c}\text { No. of eggs } \\
\text { used }\end{array}$ & Fertilization & Eyed stage & Hatch-out & Swim-up \\
\hline Microinjected & 100 & 100 & 77 & 74 & 70 \\
Control & 41 & 100 & 80 & 78 & 73 \\
\hline
\end{tabular}

Tissue extracts were obtained by centrifugation $(10,000 \times \mathrm{g}, 10 \mathrm{~min})$ and heated to $70^{\circ} \mathrm{C}$ for $5 \mathrm{~min}$ to inactivate endogeneous inhibitory factors. The protein concentration of the tissue extracts was measured by Bio-Rad Protein Assay Kit and $400 \mu \mathrm{g}$ of protein amounts per sample were used for CAT assay. The assay mixture contained $4 \mu \mathrm{l}$ of ${ }^{14} \mathrm{C}$-chloramphenicol $\quad(925 \mathrm{kBq} / \mathrm{m} l$, Amersham Co. Ltd.), $20 \mu \mathrm{l}$ of $4 \mathrm{~mm}$ acetyl coenzyme $A$, and tissue extract. The final volume of each reaction mixture was adjusted to $174 \mu \mathrm{l}$ with $0.25 \mathrm{M}$ Tris- $\mathrm{HCl}$ ( $\mathrm{pH} 7.5$ ). Positive controls contained CAT (2.8 units) instead of the tissue extract. This assay mixture was incubated for $2 \mathrm{~h}$ at $37^{\circ} \mathrm{C}$. Then, $20 \mu \mathrm{l}$ of $4 \mathrm{~mm}$ acetyl coenzyme $A$ was added to the mixture again and further incubation was carried out overnight. The reaction was stopped by extraction with $600 \mu l$ of ethyl acetate. The organic layer was dried, resuspended in $15 \mu \mathrm{l}$ of ethyl acetate, spotted on a silica gel thin layer plate, run with chloroform-methanol (95:5), and autoradiographed.

\section{Results}

Survival of 100 microinjected eggs was $77 \%$ at the eyed stage, $74 \%$ at hatching, and $70 \%$ at swimming-up. These data were similar to those of the control group (Table 1). In addition, these swim-up fry grew normally, as judged by external features and behavior.

To confirm the existence of RSV-CAT, Southern blot analysis was performed, using Hind III-and Hinc II-digested DNA of 70-day-old fish (Fig. 3). After digestion of RSV-CAT with Hind III and Hinc II, a $1.5 \mathrm{~kb}$ fragment was observed (Fig. 2). This fragment was detected in fish Nos. 1-6 and in the positive control. However, in the negative control no signals were detected (Fig. 3, N). These results suggest that RSV-CAT were present in host cells of fish Nos. 1-6. In relation to the intensity of $1.5 \mathrm{~kb}$ signals of positive controls, several copies of RSV-CAT were detected in the cells of fish Nos. 2, 3, and 6, but in fish No. 4, on average only 1 copy of RSV-CAT was detected

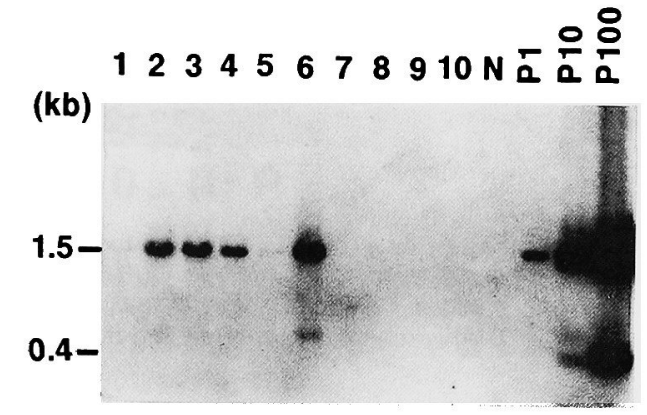

Fig. 3. Southern blot analysis of Hind III and HincII -digested rainbow trout DNA. Hind III and Hinc II-digested DNA $(10 \mu \mathrm{g})$ were electrophoresed on each lane and hybridized with ${ }^{32} \mathrm{P}$-labelled RSV-CAT fragment (2.05 kb). Lanes 1-10 contain DNA from RSV-CAT injected rainbow trout. $\mathrm{N}$ is a negative control containing DNA from non-injected rainbow trout. $\mathbf{P}_{1}, \mathbf{P}_{10}$, and $\mathrm{P}_{100}$ are positive controls of DNA from noninjected rainbow trout containing the equivalent of 1,10 , and 100 copies of RSV-CAT per cell, respectively.

in the cells. Moreover, in fish Nos. 1 and 5, less than 1 copy of RSV-CAT was observed. These positive samples were digested with Hind III and used for further Southern blot analysis. Hind III cleaved RSV-CAT at one site and generated 2 fragments of 0.4 and $1.65 \mathrm{~kb}$ (Fig. 4, right). However, Hind III digestion of all positive samples generated $2.05 \mathrm{~kb}$ fragments (Fig. 4, left). These fragments are likely to be derived from Hind III-digested head-to-tail concatemers (Fig. 4, right). In addition, in fish Nos. 2, 3, 4, and 6, $3.3 \mathrm{~kb}$ fragments were detected (Fig. 4, left). It appears, therefore, that RSV-CAT also formed tail-to-tail concatemers in these fish (Fig. 4, right). Furthermore, these positive samples were analyzed by Southern blot hybridization, using undigested DNA and Pst I-digested DNA. Pst I did not cleave the RSVCAT. If the concatemer of RSV-CAT were integrated into the host genome, Pst I-digestion would generate the fragment containing the concatemer and flanking sequence of the site 


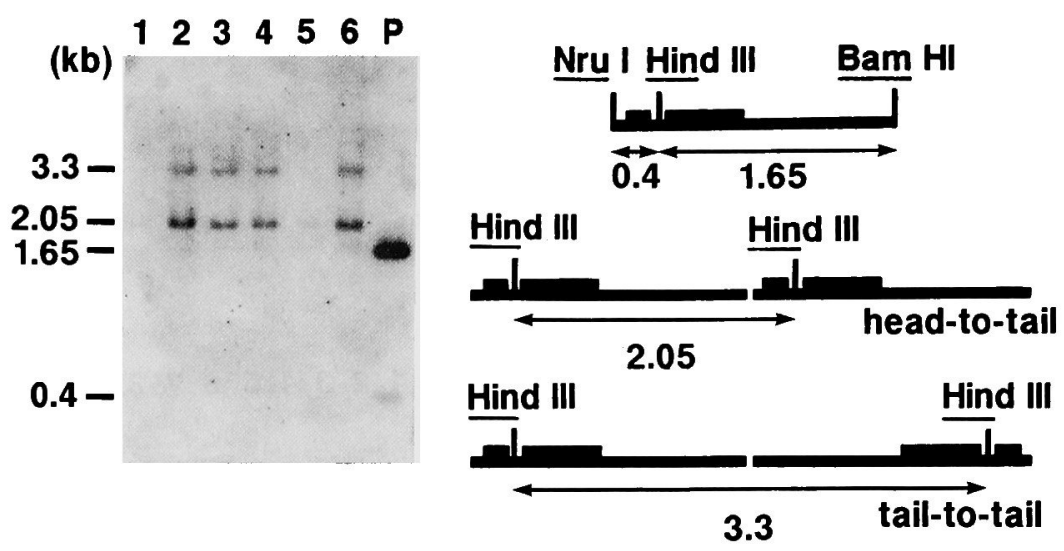

Fig. 4. Southern blot analysis of Hind III-digested rainbow trout DNA. P contains Hind IIIdigested RSV-CAT. Restriction maps at the right show the fragments generated by Hind III-digestion of head-to-tail and tail-to-tail concatenated RSV-CAT.
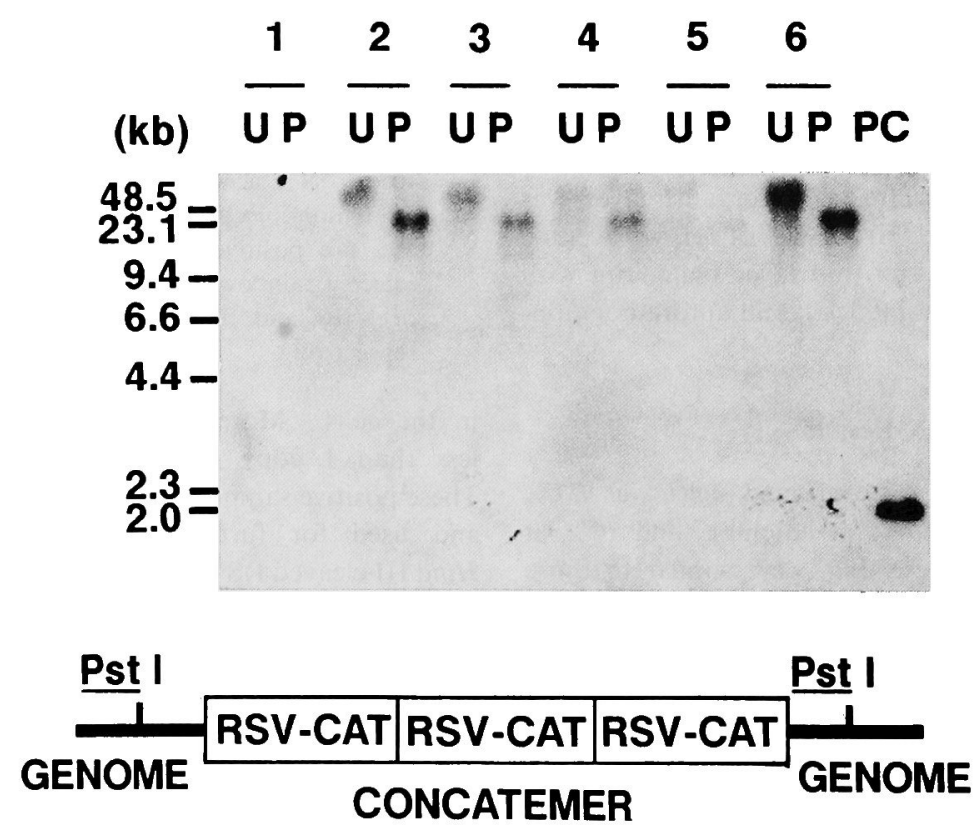

Fig. 5. Southern blot analysis of undigested rainbow trout DNA (U) and Pst I-digested DNA (P). PC contains undigested RSV-CAT. Restriction map at the bottom shows the fragment generated by Pst I-digestion of RSV-CAT concatemers integrated into the host genome.

of integration (Fig. 5, bottom), and the signals of Pst I-digested DNA would be located at a lower molecular weight than those of undigested DNA. On the other hand, if the concatemer were not integrated into the genome, Pst I-digestion would generate the fragment containing only the ex- trachromosomal concatemer, and the signals of Pst I-digested DNA would occur at the same position of undigested DNA. Figure 5 shows the result of Southern blot analysis of Pst Idigested DNA and undigested DNA. In all samples, the signals of $P$ st I digested DNA were 


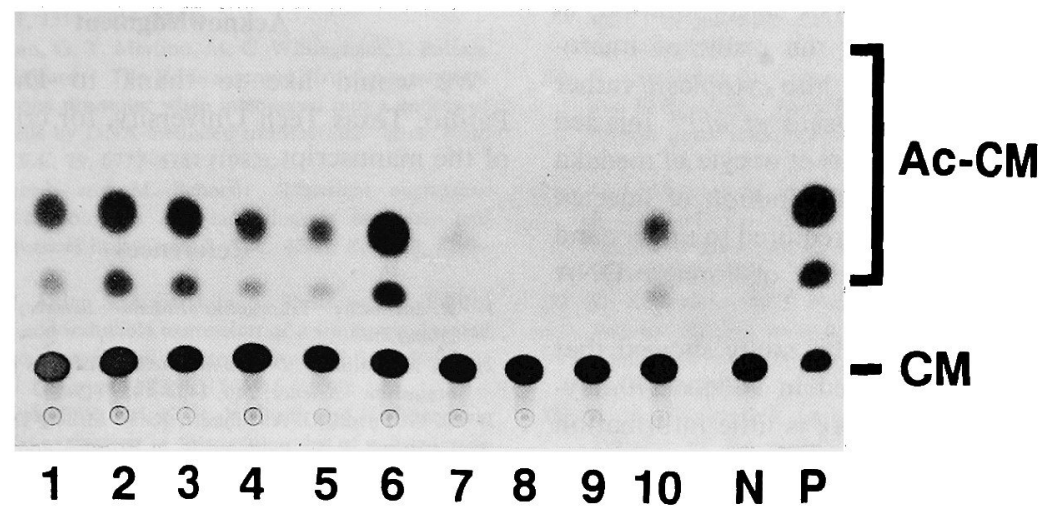

Fig. 6. Assay of CAT activity in transgenic rainbow trout. Four hundred $\mu \mathrm{g}$ of protein per individual were used for CAT assay. Each lane shows the products from chloramphenicol after incubation with 2.8 units of CAT (lane P), tissue extract of RSV-CAT injected rainbow trout (lane 1-10), and tissue extract of non-injected rainbow trout (lane N). CM: chloramphenicol, AC-CM : acetylated forms of chloramphenicol.

lower than those of undigested DNA. Therefore, these results suggest that concatemers of RSVCAT were integrated into the genome of the host.

To examine the expression of RSV-CAT in individual fish, CAT assay was performed. If the CAT gene were expressed in the host cells, the tissue extracts would actively acetylate chloramphenicol. In positive control, 1-acetylated chloramphenicol and 3-acetylated chloramphenicol were detected (Fig. 6). These acetylated chloramphenicol were also detected in samples with the exception of fish No. 8. Furthermore, there was no acetylated chloramphenicol in the negative control (Fig. 6, N). These results suggest that the injected CAT gene was expressed in rainbow trout. Surprisingly, in fish Nos. 7, 9, and 10, CAT activity was also detected, although RSVCAT was not observed by Southern blot analysis.

\section{Discussion}

The survival rate of microinjected eggs was very high in this study. The hatching rate and swimming-up rate were 95 and $96 \%$, respectively, in relation to those of non-injected control fish. These data were similar to those of transgenic trout $^{18,28,30)}$ and salmon ${ }^{31}$ previously reported.

The transformation rate was also high, as judged by Southern blot analysis (about $60 \%$ ). This high rate may be due to the microinjection of large numbers $\left(10^{7}\right)$ of copies of linear DNA. Chourrout et al. ${ }^{2 \theta)}$ and Rokkones et al. ${ }^{18)}$ obtained a high transformation rate $(75 \%)$ after microinjection of $2 \times 10^{8}$ and $10^{9}$ copies of DNA into trout eggs, respectively. In addition, linear DNA showed higher transformation efficiency than circular DNA when introduced in rainbow trout.29, 32)

We suppose that these high survival and transformation rates attained can be traced to the microinjection method. ${ }^{27)}$ Since eggs were treated with glutathione to prevent hardening of the chorion before microinjection, ${ }^{26)}$ the delivery of foreign DNA into the cytoplasm could be achieved easily and with high precision.

This study has shown that RSV-CAT were concatenated in the host genome of all positive fish. Similar findings have been observed in other transgenic fish. ${ }^{11,15,33,34)}$ Moreover, in fish Nos. 1, 5 (which carried less than 1 copy of RSV-CAT), and 4 (which carried 1 copy of RSV-CAT per cell on average), RSV-CAT also formed concatemers. These results suggest that both RSV-CAT concatemer-integrated and nonintegrated cells coexisted in mosaic fashion in the host fish. Therefore, it appears that injected RSV-CAT was replicated extrachromosomally. Thus, after serial cleavage RSV-CAT may have been integrated into the genome of each cell following formation of concatemers. This mosaic distribution of transformed cells has been reported also in zebrafish, ${ }^{15}{ }^{134)}$ carp, ${ }^{16)}$ and rainbow trout. ${ }^{27,30,35)}$ However, in transgenic mice produced by microinjection of foreign DNA into the pronucleus, mosaicism were rare. Therefore, 
the mosaic pattern of DNA incorporation in studies with fish could be the result of microinjecting the foreign DNA into cytoplasm rather the nucleus of the egg. Ozato et al. ${ }^{102}$ injected foreign DNA into the nucleus of oocyte of medaka and also reported mosaic distribution of injected DNA. Further studies are required to understand the mechanism of integration of foreign DNA into the host genome.

The results obtained in this study showed that foreign genes were expressed in $90 \%$ of 70 -dayold fish. In salmonids, there is little information on expression of foreign genes and characterization of promoters. McEvoy et al. ${ }^{17)}$ reported that mouse metallothionein 5 ' upstream sequence had a promoter activity in transgenic rainbow trout. In addition, Inoue et al. ${ }^{10}$ showed Miw promoter activity in rainbow trout embryo and hatched fry. However, McEvoy et al. ${ }^{177}$ and Inoue et al. ${ }^{\text {a) }}$ did not report the integration of expressed foreign gene into the host genome. Moreover, Rokkones et al. $\left.{ }^{19}\right)$ confirmed translational products of mouse metallothionein-human growth hormone fusion gene only in 4-day-old rainbow trout. In medaka, Chong et al. ${ }^{11}$ also reported that the expression level of pUSVCAT was reduced after gastrulation. For stable expression of foreign gene in transgenic fish, it is necessary that foreign genes be firmly integrated into the host genome. Here we found that RSV-LTR and SV40 terminator system is effective for foreign gene expression after integration into the host genome in 70-day-old rainbow trout.

In fish Nos. 7, 9, and 10, RSV-CAT was not detected by Southern blot analysis, but CAT activity was clearly detected. This observation may be the result of remnant CAT activity of degraded RSV-CAT. Alternatively, Southern blot analysis may not have been sensitive enough to detect potentially low levels of RSV-CAT, since there would be only a few cells carrying a small number of RSV-CAT copies among many non-carrying cells.

For a more efficient and accurate expression of foreign gene in transgenic fish, it would be advantageous to develop promoters derived from fish genes or fish-virus gene. Recently, several promoters of fish genes were characterized in cultured fish cells. ${ }^{14,21,38-38)}$ Further research is in progress to determine the activity of promoter of fish gene, using transgenic rainbow trout in our laboratory.

\section{Acknowledgment}

We would like to thank to Dr. Reynaldo Patiño, Texas Tech University, for critical reading of the manuscript.

\section{References}

1) R. Jaenisch: Transgenic animals. Science, 240, 1468-1474 (1988).

2) G. M. Rubin: Drosophila melanogaster as an experimental organism. Science, 240, 1453-1459 (1988).

3) V. G. Pursel, C. A. Pinkert, K. F. Miller, D. J. Bolt, R. G. Campbell, R. D. Palmiter, R. L. Brínster, and R. E. Hammer: Genetic engineering of livestack. Science, 244, 1281-1287 (1989).

4) N. Maclean, D. Penman, and Z. Zhu: Introduction of novel genes into fish. BiolTechnology, 5, 257-261 (1987).

5) C. L. How: Transgenic fish: present status and future directions. Fish Physiol. Biochenn, 7, 409-413 (1989).

6) K. Ozato, K. Inoue, and $Y$. Wakamatsu: Transgenic fish: Biological and technical problems. Zoological Science, 6, 445-457 (1989).

7) T. T. Chen and D. A. Powers: Transgenic fish. TIB Teht, 8, 209-215 (1990).

8) N. Maclean and D. Penman: The application of gene manipulation to aquaculture. Aquaculture, 85, 1-20 (1990).

9) S. J. Yoon, E. M. Hallerman, M. L. Gross, Z. Liu, J. F. Schneider, A. J. Faras P. B. Hackett, A. R. Kapuscinski, and K. S. Guise: Transfer of the gene for neomycin resistance into goldfish, Carassus auratus. Aquaculture, $85,21-33$ (1990).

10) K. Ozato, H. Kondo, H. Inohara, T. Iwamatsu, Y. Wakamatsu, and T. S. Okada: Production of transgenic fish: introduction and expression of chicken $\delta$-crystallin gene in medaka embryos. Cell Differ., 19, 237-244 (1986).

11) S.S. Chong and J. R. Vielkind: Expression and fate of CAT reporter gene microinjected into fertilized medaka (Oryzias latipes) eggs in the form of plasmid DNA, recombinan phage particles and its DNA. Theor. Appl. Genet., 78, 369. 380 (1989).

12) K. Inoue, K. Ozato, H. Kondo, T. Iwamatsu, Y. Wakamatsu, T. Fujita, and T. S. Okada: Stage-dependent expression of chicken $\delta$-crystallin gene in transgenic fish embryos. Cell Differ. Der, 27, 57-68 (1989).

13) E. Tamiya, T. Sugiyama, K. Masaki, A. Hirose, T. Okoshi, and 1. Karube: Spatial imaging of luciferase gene expression in transgenic fish. Nuc. Acids. Res., 18, 1072 (1990).

14) Z. Liu, B. Moav, A. J. Faras, K. S. Guise, A. R. Kapuscinsk, and P. B. Hackett: Development of expression vectors for transgenic fish. Bio/Technology, 8, 1268-1272 (1990).

15) G. W. Stuart, J. R. Vielkind, J. V. McMurray, and M. Westerfield: Stable lines of transgenic zebrafish exhibit reproducible patterns of transgene expression. Development, 109, $577-584(1990)$.

16) P. Zhang, M. Hayat, C. Joyce, L. I. Gonzalez-Villasenor, C. M. Lin, R. A. Dunham, T. T. Chen, and D. A. Powers: Gene transfer, expression and inheritance of pRSV-rainbow trout-GH cDNA in the common carp, Cyprinus carpio (Linnaeus). Molec. Reproduc. Develop., 25, 3-13 (1990).

17) T. McEvoy, M. Stack, B. Keane, T. Barry, J. Sreenan, and F. Gannon: The expression of a foreign gene in salmon embryos. Aquaculture, 68, 27-37 (1988).

18) E. Rokkones, P. Alestrom, H. Skjervold, and K. M. Gautvik: Microinjection and expression of a mouse metallothionein human growth hormone fusion gene in fertilized salmonid eggs. J. Comp. Physiol. B, 158, 75I-758 (1989).

19) K. Inoue, S. Yamashita, N. Akita, T. Mitsuboshi, E. Nagahisa, T. Shiba, and T. Fujta: Histochemical detection of 
foreign gene expression in rainbow trout. Nippon Suisan Gakkaishi, 57, 1511-1517 (1991).

20) C. M. Gorman, G. T. Merlino, M. C. Willingham, I. Pastan, and B. H. Howard: The Rous sarcoma virus long terminal repeat is a strong promoter when introduced into a variety of eukaryotic cells by DNA-mediated transfection. Proc. Natl, Acod. Sci. LiSA., 79, 6777-6781 (1982).

21) H. Friedenreich and M. Schartl: Transient expression directed by homologous and heterologous promoter and enhancer sequences in fish cells. Nuc. Acids. Res., 18, 32993305 (1990).

22) K. Inoue, N. Akita, S. Yamashita, T. Shiba, and T. Fujita: Constitutive and inducible expression of a transgene directed by heterologous promoters in a trout liver cell line. Biochem. Biophys. Res. Commun., 173, 1311-1316 (1990).

23) P. A. Overbeek, S.-P. Lai, K. R. V. Quill, and H. Westphal: Tissue-specific expression in transgenic mice of a fused gene containing RSV terminal sequences. Science, 231, 15741577 (1986).

24) C. M. Gorman, L. F. Moffat, and B. H. Howard: Recombinant genomes which express chloramphenicol acetyltransferase in mammalian cells. Mol. Cell. Biol, 2, 1044-1051 (1982).

25 T. Yamamoto, J. S. Tyagi, J. B. Fagan, G. Jay, B. DeCrom" brugghe, and 1. Pastan: Molecular mechanism for the capture and excision of the transforming gene of avian sarcoma virus as suggested by analysis of recombinant clones. $J$. Virol., 35, 436-443 (1980).

26) G. Yoshizaki, T. Oshiro, and F. Takashima: Prevention of hardening of chorion and dechorionation for microinjection into fish eggs. Nippon Suisan Gakkaishi, 55, 369 (1989).

27) G. Yoshizaki, T. Oshiro, and F. Takashima: Introduction of carp a-globin gene into rainbow trout. Nippon Suisan Gakkaishi, 57, 819-824 (1991).

28) J. Sambrook, E. F. Fritsch, and T. Maniatis: Molecular Cloning, A Laboratory Manual, 2nd. edn., Cold Spring Harbor Laboratory, New York, 1989, pp. 9,44.

29) D. Chourrout, R. Guyomard, and L.-M. Houdebine: High efficiency gene transfer in rainbow trout (Salmo gairdneri Rich.) by microinjection into egg cytoplasm. Aquaculture, 51, 143-150 (1986).

30) R. Guyomard, D. Chourrout, C. Leroux, L.-M. Houdebine, and F. Pourrain: Integration and germ line transmission of foreign genes microinjected into fertilized trout eggs. Biochimie, 71, 857-863 (1989).

31) G. L. Fletcher, M. A. Shears, M. J. King, P. L. Davies, and C. L. Hew: Evidence for antifreeze protein gene transfer in atlantic salmon (Salmo salar). Can. J. Fish. Aquat. Sci, 45, 352-357 (1988).

32) D. J. Penntan, A. J. Beeching, S. Penn, and N. Maclean: Factors affecting survival and integration following microinjection of novel DNA into rainbow trout eggs. Aquaculture, 85, 35-50 (1990).

33) R. A. Durham, J, Eash, J. Askins, and T. M. Townes: Transfer of the metallothionein-human growth hormone fusion gene into channel catfish. Trans. Am. Fish. Soc, 116, 87-91 (1987).

34) G. W. Stuart, J. V. McMurray, and M. Westerfield: Replication, integration and stable germ-line transmission of foreign sequences injected into early zebrafish embryos. Developntent, 103, 403-412 (1988).

35) G. Yoshizaki, T. Oshiro, F. Takashima, I. Hirono, and T. Aoki: Germ line transmission of carp a-globin gene in rainbow trout. Nippon Suisan Gakkaishi, 57, 2203-2207 (1991).

36) M. Zafarullah, K. Bonham, and L. Gedamu: Structure of the rainbow trout metallothionein $B$ gene and characterization of its metal-responsive region. Mol. Cell. Biol., 8, 44694476 (1988).

37) M. Zafarullah, P. E. Olsson, and L. Gedamu: Endogenous and heavy metal-ion-induced metallothionein gene expression in salmonid tissues and cell lines. Gene, 83, 85-93 (1989).

38) F.I. Juan and T. Aoki: Expression of foreign genes in tissue cultured fish cells. Nippon Suisan Gakkaishi, 57, 1689-1696 (1991). 